\title{
JPEB
}

Jurnal Penelitian Ekonomi dan Bisnis, 5 (1), 2020, Hal: 52 - 65

http://www.jpeb.dinus.ac.id

\section{ANALISIS PENGARUH INTENSITAS MODAL, INTENSITAS PERSEDIAAN, KOMISARIS INDEPENDEN DAN KEPEMILIKAN MANAJERIAL TERHADAP ETR}

\author{
Muhammad Syamsuddin ${ }^{1 *}$ dan Trisni Suryarini ${ }^{2}$ \\ 1,2Jurusan Akuntansi, Fakultas Ekonomi, Universitas Negeri Semarang \\ Kampus Sekaran, Gunungpati, Semarang, Indonesia \\ *Corresponding Author : syamsuddinmuhammad25@gmail.com
}

Diterima: Oktober 2019; Direvisi: Januari 2020; Dipublikasikan: Maret 2020

\begin{abstract}
This study aims to analyze the effect of capital intensity, inventory intensity, independent board of commissioners and managerial ownership on the effective tax rate. The population in this study are manufacturing companies listed on the Indonesia Stock Exchange (IDX) in 2015-2017. The sample selection uses the purposive sampling method. The results of the sample selection obtained a final sample of 75 companies with an analysis unit of 225. The data analysis of this study used descriptive statistical analysis and Structural Analysis Modeling (SEM) with AMOS 22 software. The results showed that inventory intensity had a significant positive effect on ETR, while for intensity capital, independent board of commissioners and managerial ownership, have no significant effect on ETR. The conclusion of this study is that the size of ETR in manufacturing companies is influenced by inventory intensity. Whereas capital intensity, independent board of commissioners and managerial ownership in manufacturing companies cannot influence the size of the ETR value.
\end{abstract}

Keywords: ETR; Capital Intensity; Managerial ownershi

\begin{abstract}
ABSTRAK
Penelitian ini bertujuan untuk menganalisis pengaruh intensitas modal, intensitas persediaan, dewan komisaris independen dan kepemilikan manajerial terhadap effective tax rate. Populasi dalam penelitian ini adalah perusahaan manufaktur yang terdaftar di Bursa Efek Indonesia (BEI) pada tahun 2015-2017. Pemilihan sampel menggunakan metode puposive sampling. Hasil seleksi sampel diperoleh sampel akhir sebanyak 75 perusahaan dengan unit analisis sebanyak 225. Analisis data penelitian ini menggunakan analisis statistik deskriptif dan Structural Analysis Modelling (SEM) dengan software AMOS 22. Hasil penelitian menunjukkan bahwa intensitas persediaan berpengaruh positif signifikan terhadap ETR, sedangkan untuk intensitas modal, dewan komisaris independen dan kepemilikan manajerial, tidak berpengaruh signifikan terhadap ETR. Simpulan dari penelitian ini adalah besar kecilnya ETR dalam perusahaan manufaktur dipengaruhi oleh intensitas persediaan. Sedangkan intensitas modal, dewan komisaris independen dan kepemilikan manajerial dalam perusahaan manufaktur tidak dapat mempengaruhi besar kecilnya nilai ETR.
\end{abstract}

Kata Kunci: ETR; Intensitas Modal; Kepemilikan Manajerial

DOI: $10.33633 /$ jpeb.v5i1.2707 


\section{PENDAHULUAN}

Pajak adalah salah satu bagian yang penting di dalam penerimaan pendapatan negara, menurut Undang-Undang Republik Indonesia Nomor 28 Tahun 2007 Pasal 1 ayat (1), pajak merupakan kontribusi wajib kepada negara yang dibayarkan oleh wajib pajak orang pribadi atau badan yang bersifat memaksa, dengan tidak mendapatkan imbalan secara langsung dan digunakan untuk kemakmuran rakyat (Damayanti, 2015). Pajak yang dipungut negara merupakan sumber dana yang digunakan untuk pembiayaan pengeluaran pemerintah dan digunakan untuk melaksanakan kebijakan di bidang sosial maupun ekonomi yang bertujuan untuk kemakmuran rakyat. Meskipun dianggap sebagai kontribusi wajib namun nyatanya pendapatan pajak masih dibawah target yang telah ditetapkan.

Data terkini menujukkan bahwa penerimaan pajak selama tahun 2017 mencapai mencapai Rp 1.151,10 T. Penerimaan tersebut tercatat 89,68\% dari target Anggaran Penerimaan dan Belanja Negara Perubahan (APBNP) 2017 yang sebesar Rp 1.283,57 T, realisasi tersebut tumbuh sebesar 4,08\% jika dibandingkan dengan penerimaan pajak pada tahun sebelumnya. Ini menunjukkan bahwa penerimaan pendapatan dari sektor pajak tidak sesuai dengan apa yang diharapkan, meskipun lebih besar dari tahun sebelumnya.

Penghindaran pajak (Tax Avoidance) merupakan suatu tindakan yang dianggap legal (Zain, 2008). Penghidaran pajak tidak melanggar hukum dan bahkan dapat memperoleh penghematan pajak dengan cara melakukan pemanfaatan melalui kelonggaran aturan yang telah ditetapkan, sehingga dapat menghemat pengeluaran biaya pajak. Dengan menggunakan tarif pajak efektif (effective tax rate) dapat dikategorikan sebagai pengukuran perencanaan pajak yang efektif. Banyak upaya kebijakan yang dapat dilakukan perusahaan untuk mendapatkan hasil yang optimal yaitu meminimalkan biaya pengeluaran pajak termasuk dengan menggunakan langkah pemilihan metode akuntansi untuk menurunkan besaran pajak secara efektif. Pengukuran ini dapat dilakukan dengan cara menggunakan tarif pajak efektif. Effective Tax Rate sering kali digunakan sebagai salah satu acuan oleh para pembuat keputusan untuk membuat kebijakan di dalam perusahaan dan membuat kesimpulan sistem perpajakan dalam perusahaan. Sesuai dengan Karayan dan Swenson (2007), salah satu cara untuk mengukur baik buruknya sebuah perusahaan dalam mengelola pajaknya adalah dengan melihat berapa besar tarif efektifnya.

Penelitian hubungan antara effective tax rate dengan intensitas modal, Ardyansah dan Zulaikha (2014) menemukan bahwa variabel intensitas modal tidak memiliki pengaruh yang signifikan terhadap ETR, sama halnya dengan penelitian yang dilakukan Chiou, Hsieh and Lin (2015) yang menemukan bahwa kepemilikan aset tetap tidak memiliki hubungan dengan tarif pajak.

Penelitian antara hubungan effective tax rate dengan Intensitas Persediaan, Dalam penelitian yang dilakukan Chiou, Hsieh and Lin (2015) menemukan bahwa Intensitas persediaan memiliki pengaruh positif dengan tarif pajak, Selain itu penelitian yang dilakukan Amelia (2014) menemukan bahwa Intensitas Persediaan tidak memiliki hubungan signifikasi terhadap ETR.

Penelitian hubungan antara effective tax rate dengan Dewan Komisaris Independen, penelitian yang dilakukan Ardyansah dan Zulaikha (2014) menemukan bahwa variabel dewan komisaris independen diketahui memiliki pengaruh positif signifikan terhadap ETR. Perusahaan yang memiliki proporsi komisaris independen yang lebih banyak akan melaporkan beban pajak yang lebih tinggi, sama halnya dengan penelitian yang dilakukan Wulandari dan Dovi (2015) menemukan bahwa proporsi dewan komisaris independen berpengaruh langsung terhadap effective tax rate (ETR), sedangkan Sabli (2012) menemukan bahwa mekanisme corporate governance internal maupun eksternal tidak memiliki pengaruh terhadap effective tax rate perusahaan. Ini disebabkan perusahaan mempunyai ketergantungan yang tinggi pada bantuan konsultan pajak dari pada manajemenperusahaan. 
Muhammad Syamsuddin dan Trisni Suryarini: Analisis Pengaruh Intensitas Modal, Intensitas Persediaan, Komisaris Independen Dan Kepemilikan Manajerial Terhadap ETR

Penelitian hubungan antara effective tax rate dengan Kepemilikan Manajerial, Penelitian yang dilakukan Wulandari dan Dovi (2014) menemukan bahwa Kepemilikan manajerial tidak berpengaruh signifikan terhadap effective tax rate (ETR), sedangkan Sabli (2012) menemukan bahwa mekanisme corporate governance internal dan eksternal tidak mempengarui effective tax rate perusahaan.

Penelitian ini bertujuan untuk menganalisis pengaruh intensitas modal, intensitas persediaan, dewan komisaris independen dan kepemilikan manajerial terhadap effective tax rate. Orisinalitas dari penelitian ini adalah peneliti mencoba menguji pengaruh antara effective tax rate dengn faktor-faktornya dimana dalam penelitian ini peneliti mencoba untuk memasukkan faktor keuangan dan non keuangan dalam penelitian. Penelitian ini menggunakan teknik analisis Structural Analysis Modelling (SEM) model path analysis dengan menggunakan software AMOS 22.

\section{TINJAUAN PUSTAKA}

Teori agensi dalam penelitian ini digunakan untuk menyelaraskan kepentingan antara prinsipal dengan agen agar memiliki tujuan yang sama dengan menggunkan komisaris independen sebagai penengah perbedaan kepentingan antara prinsipal dengan agen.

Teori atribusi adalah teori yang menjelaskan perilaku individu. Teori ini telah dicetuskan oleh Fritz Heider pada tahun 1958. Ikhsan dan Ishak (2005) menyatakan dalam teori atribusi dipelajari tentang bagaimana cara seseorang menjelaskan suatu peristiwa, alasan, ataupun sebab perilakunya. Penelitian ini teori atribusi digunakan menjelaskan hubungan antara kepemilikan manajerial dengan tax avoidance. Eksekutif perusahaan merupakan pihak yang mempunyai wewenang untuk membuat kebijakan serta menentukan keputusan berkaitan dengan operasi perusahaan. Adanya kepemilikan saham akan menjadian seorang eksekutif menjadi bagian dari pemilik perusahaan. Sehingga, keputusan yang ada kaitannya dengan operasi bisnis dapat dilakukan lebih baik dengan adanya kepimilikan saham oleh manajemen.

Teori kepatuhan adalah teori yang menjelaskan suatu kondisi seseorang harus patuh terhadap aturan yang ditetapkan. Berhubungan dengan tarif pajak efektif teori ini akan melandaskan agar wajib pajak badan baik manajemen ataupun yang berkaitan dengan perusahaan lainya dapat melakukan tugas sesuai dengan tugasnya, dimana tarif pajak yang dikenakan sesuai dengan tarif pajak yang berlaku tidak melakukan kecurangan-kecurangan.

Dalam penelitian ini ada beberapa faktor yang kemungkinan mempengaruhi tarif pajak yaitu intensitas modal, intensitas persediaan, komisaris independen, dan kepemilikan manajerial yang perlu dipehatikan.

\section{$\mathrm{H}_{1}$ : Intensitas modal berpengaruh negatif signifikan terhadap effective tax rate.}

Menurut Novia dan Meiranto (2015), intensitas modal adalah kegiatan atau aktivitas investasi perusahaan yang kaitanya dengan investasi aset tetap dan persediaan. Berdasarkan teori kepatuhan aktiva tetap yang dimiliki oleh perusahaan memungkinkan akan digunakan untuk memotong pajak akibat dari penyusutan setiap tahunya. Metode penyusutan aset yang di bebankan setiap tahun dapat dikurangkan pada laba sebelum pajak, sehingga akan mengurangi jumlah tarif pajak yang dikenakan. Intensitas modal sering dikaitkan dengan kepemiikan aktiva tetap dan persediaan oleh sebuah perusahaan. Rodriguez dan Arias (2012) menyebutkan aktiva tetap yang dimiliki oleh perusahaan memungkinkan digunakan untuk memotong pajak akibat depresiasi aktiva tetap setiap tahunnya. Ini menunjukkan bahwa perusahaan yang memiliki aktiva tetap yang cederung tinggi memiliki beban pajak yang lebih rendah dibanding dengan perusahaan yang mempunyai aktiva tetap yang rendah.

Penelitian yang dilakukan Kartika Pertiwi (2016) mendapatkan intensitas aset tetap berhubungan positif dengan ETR. Sedangkan penelitian yang dilakukan oleh Amelia (2014) menyatakan bahwa kepemilikan aset tetap tidak memiliki pengaruh parsial terhadap Effective 
Tax Rate. Hal ini karena perusahaan yang sudah besar biasanya asset tetap yang digunakan sudah habis masa manfaatnya (Vidiyanna dan Rizal Putri, 2018). Penelitian ini juga sesuai dengan hasil dari Ardyansah dan Zulaikha (2014) yang menyatakan bahwa capital intensity ratio tidak memiliki hubungan negatif signifikan terhadap ETR.

Liu (2007) menyebutkan bahwa biaya depresiasi dapat dikurangkan pada laba sebelum pajak melalui metode penyusutan. Dengan demikian semakin besar aktiva tetap dan biaya depresiasi, perusahaan akan mempunyai ETR yang rendah. Sabli dan Noor (2012) menjelaskan perusahaan yang mempunyai aset tetap yang tinggi lebih cenderung melakukan perencanaan pajak, sehingga mempunyai effective tax rate yang rendah.

\section{$\mathrm{H}_{2}$ : Intensitas persediaan berpengaruh positif signifikan terhadap effective tax rate}

Intensitas persediaan merupakan cerminan besaran perusahaan dalam berinvestasi terhadap persediaan yang terdapat didalam perusahaan (Halim, 2016). Intensitas persediaan menggambarkan bagaimana sebuah perusahaan dapat menginvestasikan kekayaan yang dimiliki dalam bentuk persediaan. Besarnya persediaan tersebut akan memuncukan biayabiaya tambahan antara lain biaya penyimpanan ataupun biaya kerusakan barang dalam gudang. PSAK. NO 14 mengatur tentang biaya yang timbul atas kepemilikan persediaan yang besar harus di keluarkan dari biaya tambahan atas adanya persediaan yang besar akan menyebabkan berkurangnya laba perusahaan.

Penelitan yang telah dilakukan oleh Amelia (2014) yang menyatakan bahwa Intensitas Persediaan tidak memiliki hubungan parsial terhadap ETR. Berbeda dengan penelitian Chiao et al (2012) yang menyatakan bahwa intensitas persediaan memiliki hubungan signifikan terhadap Effective Tax Rate, begitu juga dengan hasil dari penelitian Kartika Pertiwi (2016) yang menyatakan bahwa intensitas persediaan berpengaruh terhadap tarif pajak efektif pada perusahaan manufaktur

Banyak cara yang dilakukan manajer misalnya meminimalisisir beban untuk agar tidak mengurangi laba, adapula yang membebankan biaya-biaya tambahan untuk mengurangi laba yang dimiki sehingga dapat menekan jumlah pajak yang dikeluarkan. Jika laba yang dibebankan mengecil mengakibatkan menurunya pajak yang dibayarkan oleh perusahaan. Namun biaya-biaya tersebut oleh perusahaan sering kali tidak dijadikan sebagai pengurang penghasilan kena pajak sehingga tidak dapat dijadikan sebagai tax shield. Noor et al. (2010) dalam penelitiannya menyatakan bahwa perusahaan lebih cenderung meminimalkan ETR dengan menggunakan utang, menginvestasikan lebih besar pada aset tetap dan memiliki investasi yang rendah pada persediaan, atau kata lain perusahaan lebih memilih intensitas persediaan yang tinggi dan memiliki ETR yang tinggi pula (Richardson dan Lanis, 2007).

\section{$\mathrm{H}_{3}$ : Komisaris independen berpengaruh positif signifikan terhadap effective tax rate}

Dewan komisaris adalah organ perseroan yang memiliki tugas melakukan pengawasan secara umum dan/atau khusus sesuai dengan anggaran dasar perusahaan serta bertugas memberikan nasihat kepada dewan direksi, selain itu komisaris independen merupakan anggota komisaris yang tidak memiliki hubungan afiliasi dengan anggota komisaris lainnya, anggota dewan direksi, pemilik saham pengendali ataupun pemilik saham lainya sehingga tidak mempengaruhi ke independenannya. Jumlah komisaris independen proporsional dengan jumlah saham yang dimiliki oleh non-pemegang saham pengendali. Menurut Undang-Undang Nomor 40 tahun 2007 tentang PT menyebutkan bahwa komisaris independen diangkat berdasarkan keputusan RUPS dari pihak yang tidak terafiliasi dengan pemegang saham utama, anggota direksi atau anggota dewan komisaris lainnya. Syarat mengenai komisaris independen yang wajib ada dalam jajaran dewan komisaris menunjukkan bahwa peranan dari komisaris independen sendiri sangatla penting bagi perusahaan tersebut. Teori agensi menyatakan bahwa dewan komisaris independen yang semakin banyak, menunjukkan semakin baik didalam 
Muhammad Syamsuddin dan Trisni Suryarini: Analisis Pengaruh Intensitas Modal, Intensitas Persediaan, Komisaris Independen Dan Kepemilikan Manajerial Terhadap ETR

mengawasi dan mengontrol tindakan-tindakan manajemen dalam perusahaan sehubungan dengan perilaku oprerasional perusahaan.

Sabli dan Noor (2012) menyebutkan bahwa semakin baik pengawasan yang dilakukan oleh dewan komisaris akan membawa manajemen perusahaan untuk semakin taat akan peraturan yang telah ditetapkan. Komisaris independen melakukan pengarahan dan mengawasi agar tidak terjadi kesalahan informasi yang sering terjadi antara pihak prinsipal dan pihal agen. Sehingga keberadaannya akan membuat manajemen selalu berhati-hati dalam mengambil keputusan-keputusan yang sehubungan dengan kebijakan perusahaan. Selain itu keberadaan komisaris independen dalam suatu perusahaan dapat menjadi penengah antara prinsipal dan pihak agen dalam mengambil kebijakan agar tidak melanggar hukum termasuk dalam menentukan strategi yang terkait dengan perencanaan pajak. Pengawasan yang semakin ketat dari dewan komisaris independen dapat mendorong manajemen untuk taat pada peraturan perpajakan yang berlaku dalam menyusun laporan keuangan.

Komisaris independen sebagai pihak luar atau pihak yang tidak memiliki hubungan dengan manajemen maupun para pemegang saham dalam menjalankan tugasnya tidak memperoleh intervensi dari pihak manapun, sehingga mereka mampu melakukan pengawasan kinerja perusahaan dengan baik dan netral. Keberadaan komisaris independen yang semakin tinggi dapat memberikan pengawasan yang ketat terhadap kinerja manajemen, sehingga manajemen dapat mengungkapkan beban pajaknya sesuai dengan yang sebenarnya.

Penelitian yang dilakukan oleh Amelia (2014) yang menyatakan bahwa Dewan Komisaris Independen tidak memiliki pengaruh parsial terhadap Effective Tax Rate. Hanum (2013) Komisaris independen yang merupakan bagian dari dewan komisaris kurang efektif dalam melakukan pengawasan terhadap manajemen perusahaan, Yeye, Widyawat Ratih dan Nuraini (2018) hal ini dikarenakan Komisaris independen bertugas mengawasi kebijakan dan pelaksanaan kebijakan yang dibuat perusahaan, komisaris independen yang ada hanya sekedar memenuhi ketentuan peraturan yang ada saja dan tidak berdampak terhadap kebijakan perusahaan termasuk kebijakan perpajakan. Kebijakan perpajakan yang dilakukan manajemen tidak terawasi, sehingga kebijakan pembayaran pajak menjadi lemah. Penelitan yang telah dilakukan oleh Ardyansah dan Zulaikha (2014) yang menyatakan bahwa dewan komisaris independen memiliki hubungan signifikan. Hal tersebut dikarenakan semakin banyak jumlah komisaris independen maka semakin besar pengaruhnya untuk melakukan pengawasan terhadap kinerja manajemen. Pengawasan yang ketat dari komisaris independen membuat manajer melaporkan kinerja perpajakan perusahaan dengan apa adanya, hal ini dilakukan untuk melindungi kesejahteraan para stakeholder.

\section{$\mathrm{H}_{4}$ : Kepemilikan manajerial berpengaruh negatif signifikan terhadap effective tax rate}

Kepemilikan Manajerial adalah kepemilikan saham oleh manajemen perusahaan yang diukur dengan persentase jumlah saham yang dimiliki oleh manajemen menurut (Sujoko dan Soebiantoro, 2007). Kepemilikan manajerial merupakan kepemilikan saham perusahaan yang dimiliki oleh manajemen baik direksi, komisaris maupun karyawan dengan persyaratan tertentu untuk memiliki saham. Menurut Boediono (2005) kepemilikan manajerial merupakan jumlah dari kepemilikan saham oleh pihak manajemen dari seluruh modal saham perusahaan yang dikelola. Kepemilikan saham oleh manajemen akan mengurangi masalah diantara manajer dan pemegang saham yang dapat dicapai melalui penyelarasan tujuan. Teori atribusi menyatakan bahwa semakin besar proporsi kepemilikan manajerial dalam perusahaan maka manajemen akan berupaya lebih giat untuk memenuhi kepentingan pemegang saham yang juga adalah dirinya sendiri.

Kepemilikan manajerial dapat memotivasi manajer untuk meningkatkan kinerjanya sehingga akan berdampak baik terhadap perusahaan serta memenuhi tujuan dari para pemegang saham. Dengan berpedoman pada peraturan perpajakan besarnya kepemilikan 
manajerial dalam perusahaan dapat berpengaruh terhadap manajemen yaitu manajemen akan lebih giat untuk meningkatkan kinerjanya karena manajemen mempunyai tanggungjawab untuk memenuhi keinginan dari pemegang saham yang tidak lain adalah dirinya sendiri.

Penelitian yang dilakukan oleh Wulandari dan Dovi (2015) yang menyatakan bahwa Kepemilikan Manajerial tidak memiliki hubungan signifikan terhadap Effective Tax Rate, hal ini dikarenakan persentase kepemilikan manajerial yang tergolong kecil dibandingkan investor lainnya akan mengakibatkan manajer tidak dapat mempengaruhi kebijakan manajemen dalam penyusunan kebijakan pengelolaan pajak efektif. Hadi dan Mangoting (2014), rata-rata persentase kepemilikan saham manajerial yang relatif kecil mengindikasi bahwa perusahaan dikendalikan oleh pemegang saham lainnya.

Penelitian yang dilakukan Boussaidi (2015), menemukan bahwa besarnya kepemilikan saham manajerial yang lebih besar berpengaruh dalam melakukan penentuan pengukuran perencanaan pajak, semakin banyak manajemen memiliki saham dalam suatu perusahaan maka semakin besar upaya manajemen untuk melakukan pengelolaan pajak efektif. Besarnya upaya yang dilakukan untuk melakukan pengelolaan pajak efektif diyakini dapat menurunkan nilai ETR. Nilai ETR yang rendah sendiri dapat memaksimalkan return bagi pemegang saham termasuk manajemen sebagai pengelola sekaligus sebagai pemilik perusahaan.

Kerangka berpikir dalam penelitian ini dapat digambarkan sebagai berikut:

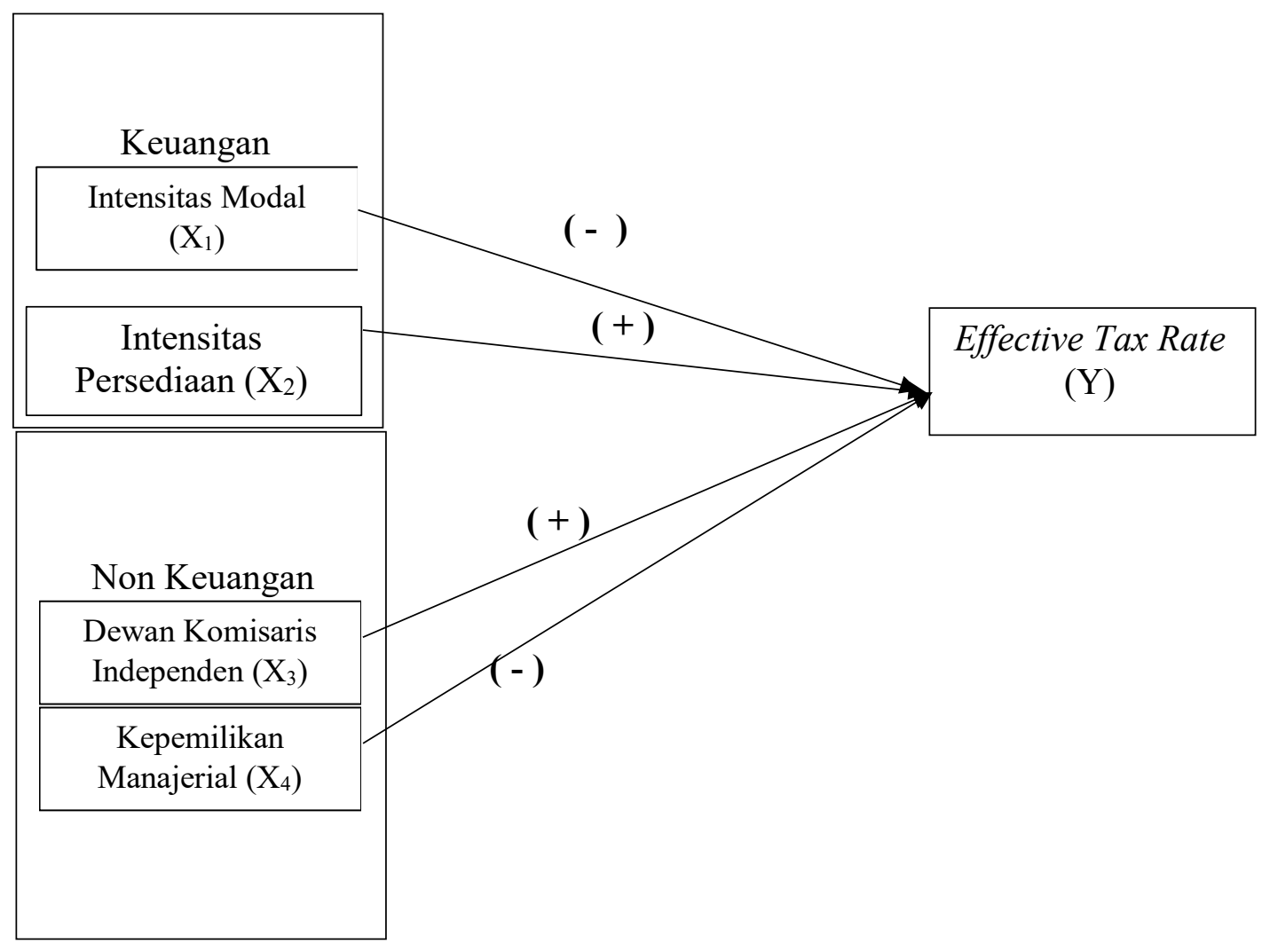

Gambar 1. Kerangka Teoritis

Berdasarkan kerangka berpikir di atas, Penulis merumuskan empat hipotesis penelitian sebagai berikut:

$\mathrm{H}_{1}=$ Intensitas modal berpengaruh negatif signifikan terhadap effective tax rate.

$\mathrm{H}_{2}=$ Intensitas persediaan berpengaruh positif signifikan terhadap effective tax rate.

$\mathrm{H}_{3}=$ Dewan komisaris independen berpengaruh positif signifikan terhadap effective tax rate.

$\mathrm{H}_{4}=$ Kepemilikan manajerial berpengaruh negatif signifikan terhadap effective tax rate. 
Muhammad Syamsuddin dan Trisni Suryarini: Analisis Pengaruh Intensitas Modal, Intensitas Persediaan, Komisaris Independen Dan Kepemilikan Manajerial Terhadap ETR

\section{METODE PENELITIAN}

Penelitian ini merupakan penelitian kuantitatif dengan menggunakan data sekunder. Populasi dalam penelitian ini adalah perusahaan manufaktur yang terdaftar di Bursa Efek Indonesia (www.idx.co.id) periode 2015-2017 yang terdiri dari 144 perusahaan. Sampel dipilih menggunakan metode purposive sampling, dan diperoleh 75 perusahaan sehingga unit analisis yang digunakan sebanyak 225 unit analisis. Kriteria pemilihan dapat dilihat pada tabel 1

Tabel 1. Proses Seleksi Sampel

\begin{tabular}{lll}
\hline No & \multicolumn{1}{c}{ Kriteria Sampel } & Jumlah \\
\hline $1 \quad \begin{array}{l}\text { Perusahaan manufaktur yang secara berturut-turut } \\
\text { menyediakan laporan tahunan di Bursan Efek }\end{array}$ & \\
& Indonesia tahun $2015-2017$ \\
2 & $\begin{array}{l}\text { Perusahaan Yang Merugi secara berturut-turut } \\
\text { selama periode tahun 2015-2017. }\end{array}$ \\
$3 \quad \begin{array}{l}\text { Perusahaan yang tidak mempublikasikan dan (8) } \\
\text { menyajikan laporan tahunan dengan data yang }\end{array}$ \\
$\begin{array}{l}\text { lengkap sesuai data yang dibutuhkan dalam } \\
\text { penelitian ini secara berturut-turut selama periode }\end{array}$ \\
tahun 2015-2017. \\
\hline Perusahaan yang menjadi sampel penelitian & 75 \\
\hline Total pengamatan pada annual report selama periode & 225 \\
$2015-2017$ &
\end{tabular}

Penelitian ini menggunakan variabel intensitas modal, intensitas persediaan, dewan komisaris independen dan kepemilikan manajerial sebagai variabel independen. Variabel dependen dalam penelitian ini adalah effective tax rate. Definisi operasional antar variabel dapat dilihat pada Tabel 2.

\section{Tabel 2. Definisi Operasional Variabel}

\begin{tabular}{|c|c|c|c|}
\hline No & Nama Variabel & Pengukuran & Literatur \\
\hline 1 & $\begin{array}{l}\text { Effective Tax Rate } \\
\text { ETR adalah tingkat } \\
\text { pajak efektif } \\
\text { perusahaan yang } \\
\text { dapat dihitung dari } \\
\text { beban pajak } \\
\text { penghasilan (beban } \\
\text { pajak kini) yang } \\
\text { kemudian dibagi } \\
\text { dengan laba sebelum } \\
\text { pajak (Wulandari dan } \\
\text { Dovi, 2015). }\end{array}$ & $E T R=\frac{\text { Total Pajak Penghasilan }}{\text { Laba Sebelum Pajak }} \times 100 \%$ & $\begin{array}{l}\text { Rodriguez dan } \\
\text { Arias (2012), } \\
\text { Ardyansah dan } \\
\text { Zulaikha (2014), } \\
\text { Wulandari dan } \\
\text { Dovi (2015) }\end{array}$ \\
\hline 2 & $\begin{array}{l}\text { Capital intensity ratio } \\
\text { atau intensitas modal } \\
\text { adalah suatu aktivitas } \\
\text { investasi perusahaan } \\
\text { yang kaitanya dengan }\end{array}$ & Intensitas Modal $=\frac{\text { Aset Tetap }}{\text { Total Aset }} \times 100 \%$ & $\begin{array}{l}\text { Novia dan } \\
\text { Meiranto (2015), } \\
\text { Rodriguez dan } \\
\text { Arias (2012), } \\
\text { Ardyansah dan } \\
\text { Zulaikha (2014) }\end{array}$ \\
\hline
\end{tabular}




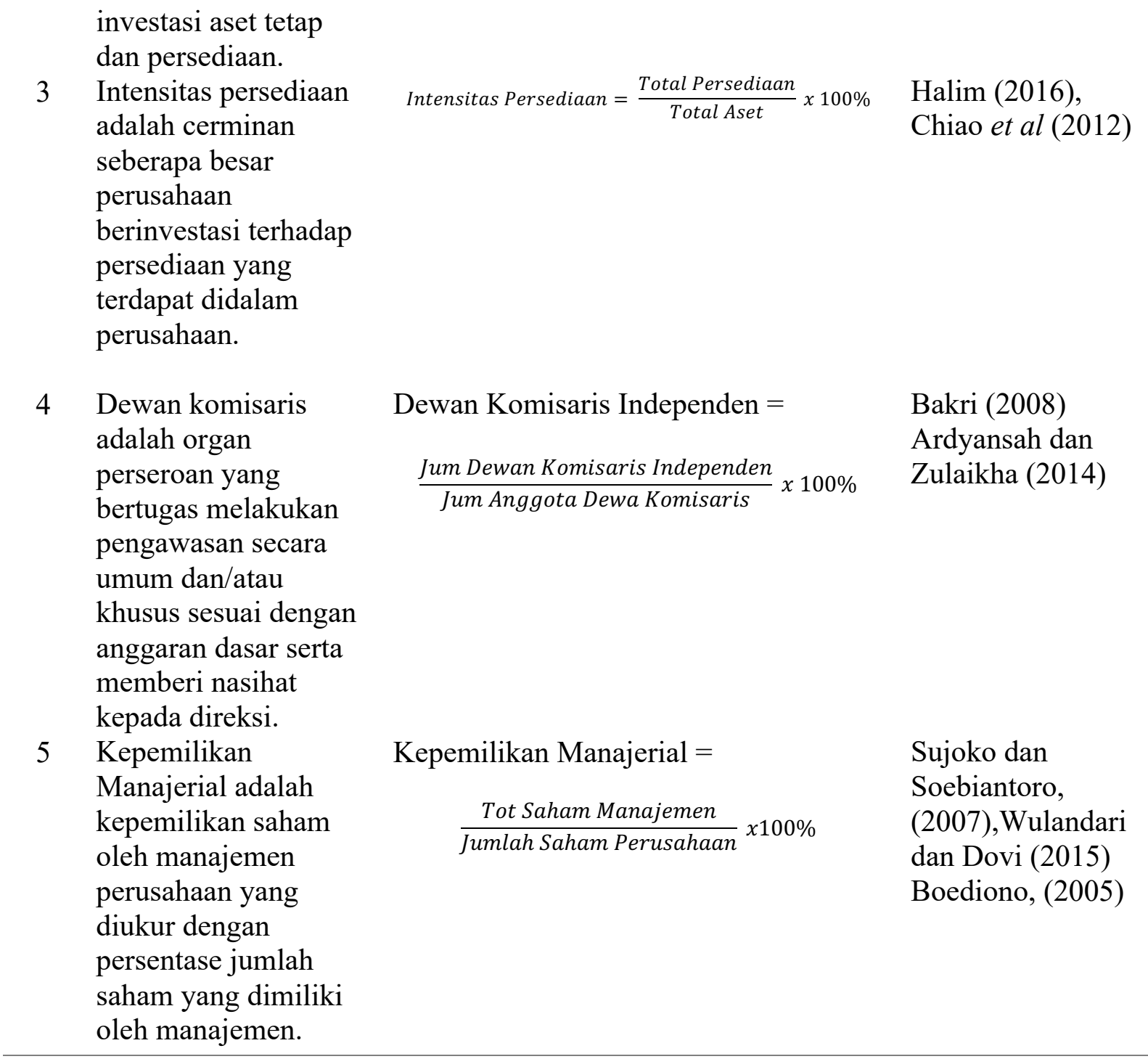

Metode pengumpulan data pada penelitian ini adalah dokumentasi. Data berupa annual report perusahaan manufaktur yang terdaftar di BEI periode 2015-2017. Pada penelitian ini akan dilakukan analisis jalur (path analysis) Structural Analysis Modelling (SEM) untuk menguji pengaruh variabel independen terhadap variabel dependen. Pengujian hipotesis dilakukan dengan analisis jalur dengan Structural Analysis Modelling (SEM).

\section{HASIL DAN PEMBAHASAN}

Hasil dari statistik deskriptif variabel intensitas modal, intensitas persediaan, dan dewan komisaris independen dan kepemilikan manajerial pada tabel 3.

Hasil analisis statistik deskriptif ETR menunjukkan bahwa nilai mean sebesar 0,3423 mendekati nilai minimum sebaran data yaitu 0,01 dan relatif jauh dari nilai maksimum sebaran data yaitu 5,80. Hal ini menunjukkan bahwa mayoritas perusahaan manufaktur memiliki ETR yang tergolong rendah. Intesitas Modal Hasil analisis statistik deskritifnya menunjukkan bahwa nilai mean sebesar 0,3668 mendekati nilai minimum sebaran data yaitu 0,04 dan relatif jauh dari nilai maksimum sebaran data yaitu 0,80 . Hal ini menunjukkan bahwa mayoritas perusahaan manufaktur memiliki tingkat intensitas modal yang rendah. Intesitas Persediaan hasil analisis statistik deskritifnya menunjukkan bahwa nilai mean sebesar 0,2023 mendekati 
Muhammad Syamsuddin dan Trisni Suryarini: Analisis Pengaruh Intensitas Modal, Intensitas Persediaan, Komisaris Independen Dan Kepemilikan Manajerial Terhadap ETR

nilai minimum sebaran data yaitu 0,01 dan relatif jauh dari nilai maksimum sebaran data yaitu 0,60. Hal ini menunjukkan bahwa mayoritas perusahaan manufaktur memiliki tingkat intensitas persediaan yang rendah. Dewan Komisaris Independen hasil analisis statistik deskritifnya menunjukkan bahwa nilai mean sebesar 0,3865 mendekati nilai minimum sebaran data yaitu 0,29 dan relatif jauh dari nilai maksimum sebaran data yaitu 0,80 . Hal ini menunjukkan bahwa mayoritas perusahaan manufaktur memiliki tingkat dewan komisaris independen yang rendah. Kepemilikan Manajerial hasil analisis statistik deskritifnya menunjukkan bahwa nilai mean sebesar 0,0372 mendekati nilai minimum sebaran data yaitu 0,20 dan relatif jauh dari nilai maksimum sebaran data yaitu 0,71 . Hal ini menunjukkan bahwa mayoritas perusahaan manufaktur memiliki tingkat kepemilikan manajerial yang rendah.

Tabel 3. Statistik Deskriptif

\begin{tabular}{cccccc}
\hline & N & Minimum & Maximum & Mean & $\begin{array}{c}\text { Std. } \\
\text { Deviation }\end{array}$ \\
\hline ETR & 225 &, 01 & 5,80 &, 3423 &, 54201 \\
Modal & 225 &, 04 &, 80 &, 3668 &, 16792 \\
Persediaan & 225 &, 01 &, 60 &, 2023 &, 11788 \\
Independen & 225 &, 29 &, 80 &, 3865 &, 08588 \\
Manajerial & 225 &, 00 &, 71 &, 0372 &, 09700 \\
Valid N & 225 & & & & \\
(listwise) & & & & & \\
\hline
\end{tabular}

Hasil pengujian analisis jalur (path analysis) Structural Analysis Modelling (SEM) untuk menguji pengaruh variabel independen terhadap variabel dependen menunjukkan :

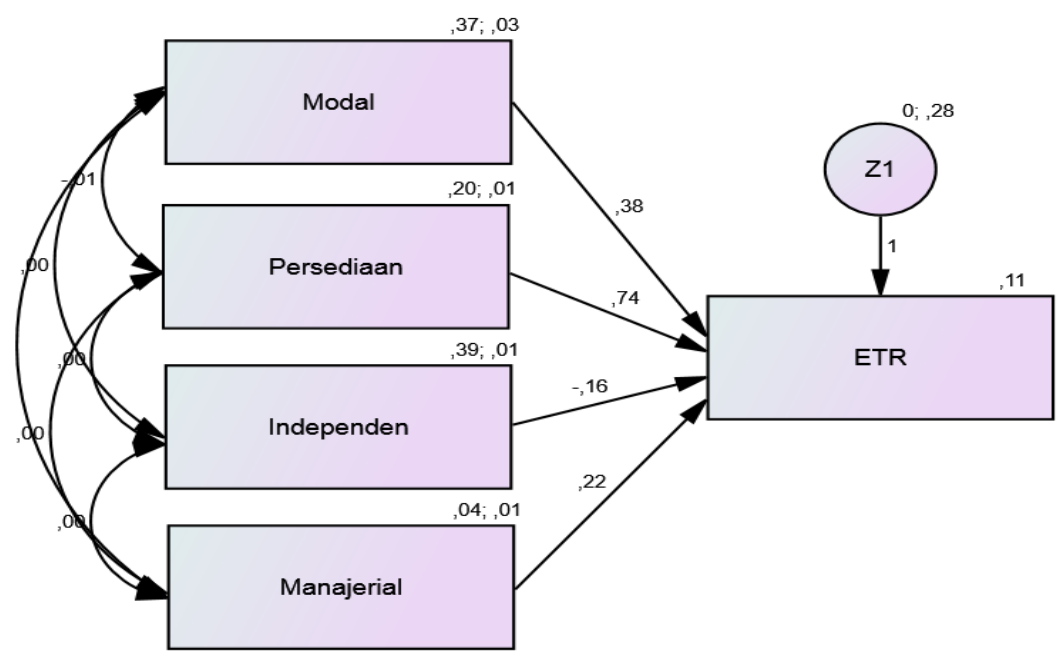

Gambar 2. Path Analisis 
Tabel 4. Regression Weights

\begin{tabular}{lccccccc}
\hline & & & Estimate & S.E. & C.R. & P & Label \\
\hline ETR & $<---$ & Modal &, 377 &, 232 & 1,622 &, 105 & \\
ETR & $<---$ & Persediaan &, 741 &, 329 & 2,251 &, 024 & \\
ETR & $<---$ & Independen &,- 162 &, 427 &,- 380 &, 704 & \\
ETR & $<---$ & Manajerial &, 223 &, 374 &, 597 &, 551 & \\
\hline
\end{tabular}

Uji hipotesis dilakukan untuk mengetahui berpengaruh atau tidaknya variabel independen terhadap variabel dependen. Hipotesis dinyatakan diterima jika nilai prob $(\mathrm{P})<$ 0,05 atau 5\% dan nilai $\mathrm{P}<0,1$ atau $10 \%$. Hasil uji hipotesis dapat dilihat pada tabel dibawah ini:

Tabel 5. Ringkasan Pengujian Hipotesis

\begin{tabular}{|c|c|c|c|c|}
\hline No & Hipotesis & $\alpha$ & $\mathbf{P}$ & Hasil \\
\hline 1. & $\begin{array}{l}\mathrm{H}_{1} \text { : Intensitas modal berpengaruh } \\
\text { positif signifikan terhadap Effective } \\
\text { Tax Rate. }\end{array}$ & 0.05 & 0,105 & Ditolak \\
\hline 2. & $\begin{array}{l}\mathrm{H}_{2} \text { : Intensitas persediaan berpengaruh } \\
\text { negatif signifikan terhadap Effective } \\
\text { Tax Rate }\end{array}$ & 0.05 & 0,024 & Diterima \\
\hline 3. & $\begin{array}{l}\mathrm{H}_{3} \text { : Dewan komisaris independen } \\
\text { berpengaruh negatif Signifikan } \\
\text { terhadap Effective Tax Rate }\end{array}$ & 0.05 & 0,704 & Ditolak \\
\hline 4. & $\begin{array}{l}\mathrm{H}_{4} \text { : kepemilikan manajerial } \\
\text { berpengaruh positif Signifikan } \\
\text { terhadap Effective Tax Rate }\end{array}$ & 0.05 & 0,551 & Ditolak \\
\hline
\end{tabular}

\section{Intensitas Modal Berpengaruh Signifikan Terhadap Effective Tax Rate (ETR)}

Hasil penelitian menunjukkan bahwa Intensitas modal tidak berpengaruh signifikan terhadap Effective Tax Rate sehingga dapat disimpulkan H1 Intensitas modal berpengaruh negatif signifikan terhadap effective tax rate (ETR) pada penelitian ini ditolak. Hasil ini sesuai dengan hasil penelitian yang dilakukan oleh Amelia (2014) dan Chiao et al (2012) yang menyatakan bahwa kepemilikan aset tetap tidak memiliki pengaruh parsial terhadap Effective Tax Rate. Penelitian ini juga sesuai dengan hasil dari Ardyansah dan Zulaikha (2014) yang menyatakan bahwa capital intensity ratio tidak memiliki hubungan signifikan terhadap Effective Tax Rate.

Hasil penelitian ini juga sesuai dengan hasil yang dilakukan oleh Vidiyanna dan Rizal Putri (2018), hal ini karena perusahaan yang sudah besar biasanya aset tetap yang digunakan sudah habis masa manfaatnya. Hal ini mengakibatkan besar kecilnya aset tetap yang dimiliki oleh perusahaan tidak berpengaruh terhadap Effective Tax Rate. Hasil ini tidak sesuai dengan teori kepatuhan (compliance theory) dimana kepatuhan mengenai perpajakan merupakan tanggung jawab kepada Tuhan, bagi pemerintah dan rakyat sebagai Wajib Pajak untuk memenuhi semua kegiatan kewajiban perpajakan dan melaksanakan hak perpajakannya. Kepatuhan Wajib Pajak merupakan perilaku yang didasarkan pada kesadaran seorang Wajib Pajak terhadap kewajiban perpajakannya dengan tetap berlandaskan pada peraturan perundang-undangan yang telah ditetapkan. Kesadaran itu sendiri merupakan bagian dari motivasi yang datangnya dalam diri individu itu sendiri (intrinsik) dan motivasi yang datangnya dari luar individu, seperti dorongan dari aparat pajak untuk meningkatkan kepatuhan 
Muhammad Syamsuddin dan Trisni Suryarini: Analisis Pengaruh Intensitas Modal, Intensitas Persediaan, Komisaris Independen Dan Kepemilikan Manajerial Terhadap ETR

perpajakan (ekstrinsik). Berdasarkan hal tersebut intensitas modal belum mampu menjadi faktor yang mempengaruhi besar kecilnya nilai effective tax rate.

Namun penelitian ini menolak hasil penelitan yang telah dilakukan oleh Kartika Pertiwi (2016) yang mendapatkan Intensitas Aset Tetap berhubungan positif dengan Effective Tax Rate.

\section{Intensitas Persediaan Berpengaruh Signifikan Terhadap Effective Tax Rate (ETR)}

Hasil pengujian menunjukkan bahwa variabel Intensitas persediaan memiliki pengaruh positif signifikan terhadap variabel Effective Tax Rate, sehingga dapat disimpulkan $\mathrm{H} 2$ Intensitas persediaan berpengaruh positif signifikan terhadap effective tax rate (ETR) penelitian ini dapat diterima. Hasil ini sesuai dengan hasil penelitian yang dilakukan oleh Chiao et al (2012) yang menyatakan bahwa Intensitas Persediaan memiliki hubungan signifikan terhadap Effective Tax Rate, begitu juga dengan hasil dari penelitian Kartika Pertiwi (2016) yang menyatakan bahwa Intensitas persediaan berpengaruh terhadap tarif pajak efektif pada perusahaan manufaktur.

Hal ini karena besarnya persediaan akan memuncukan biaya tambahan yang berkaitan dengan persediaan antara lain biaya penyimpanan ataupun biaya kerusakan barang. PSAK. NO 14 mengatur biaya yang timbul atas kepemilikan persediaan yang besar harus di keluarkan dari biaya tambahan atas adanya persediaan yang besar akan menyebabkan berkurangnya laba perusahaan. Selain itu kebijakan dari manajemen perusahaan yang berusaha menekankan nilai tarif pajak menggunakan kebijakan sesuai dengan peraturan yang ada. Namun biaya-biaya tersebut oleh perusahaan sering kali tidak dijadikan sebagai pengurang penghasilan kena pajak sehingga tidak dapat dijadikan sebagai tax shield. Noor et al. (2010) dalam penelitiannya menyatakan bahwa perusahaan lebih cenderung meminimalkan ETR dengan menggunakan utang, menginvestasikan lebih besar pada aset tetap dan memiliki investasi yang rendah pada persediaan, atau kata lain perusahaan lebih memilih intensitas persediaan yang tinggi dan memiliki ETR yang tinggi pula (Richardson dan Lanis, 2007). Hasil ini sesuai dengan teori kepatuhan (compliance theory) dimana kepatuhan mengenai perpajakan merupakan tanggung jawab kepada Tuhan, bagi pemerintah dan rakyat sebagai Wajib Pajak untuk memenuhi semua kegiatan kewajiban perpajakan dan melaksanakan hak perpajakannya. Kepatuhan Wajib Pajak merupakan perilaku yang didasarkan pada kesadaran seorang Wajib Pajak terhadap kewajiban perpajakannya dengan tetap berlandaskan pada peraturan perundang-undangan yang telah ditetapkan. Kesadaran itu sendiri merupakan bagian dari motivasi yang datangnya dalam diri individu itu sendiri (intrinsik) dan motivasi yang datangnya dari luar individu, seperti dorongan dari aparat pajak untuk meningkatkan kepatuhan perpajakan (ekstrinsik).

Namun penelitian ini menolak hasil penelitan yang telah dilakukan oleh Amelia (2014) yang menyatakan bahwa Intensitas Persediaan tidak memiliki hubungan parsial terhadap Effective Tax Rate, Batmomolin (2018) yang menyatakan bahwa intensitas persediaan tidak memiliki hubungan signifikan terhadap Effective Tax Rate.

\section{Dewan Komisaris Independen Berpengaruh Signifikan Terhadap Effective Tax Rate (ETR)}

Hasil penelitian menunjukkan bahwa dewan komisaris independen tidak berpengaruh signifikan terhadap Effective Tax Rate, sehingga dapat disimpulkan H3 Dewan komisaris independen berpengaruh positif signifikan terhadap effective tax rate (ETR) pada penelitian ini ditolak. Hasil ini sesuai dengan hasil penelitian yang dilakukan oleh Amelia (2014) yang menyatakan bahwa Dewan Komisaris Independen tidak memiliki pengaruh parsial terhadap Effective Tax Rate. Hanum (2013) yang menyatakan bahwa Dewan Komisaris Independen tidak memiliki hubungan signifikan terhadap Effective Tax Rate. 
Hasil ini juga sesuai dengan penelitian yang dilakukan Yeye, Widyawat Ratih dan Nuraini (2018) hal ini dikarenakan Komisaris independen bertugas mengawasi kebijakan dan pelaksanaan kebijakan yang dibuat perusahaan. Komisaris independen tidak berpengaruh terhadap effective tax rate karena komisaris independen yang ada hanya sekedar memenuhi ketentuan peraturan yang ada saja dan tidak berdampak terhadap kebijakan perusahaan termasuk kebijakan perpajakan. Kebijakan perpajakan yang dilakukan manajemen tidak terawasi, sehingga kebijakan pembayaran pajak menjadi lemah.

Namun penelitian ini menolak hasil penelitan yang telah dilakukan oleh Ardyansah dan Zulaikha (2014) serta Wulandari dan Dovi (2015) yang menyatakan bahwa dewan komisaris independen memiliki hubungan signifikan. Hasil ini tidak didukung teori agensi dimana adanya komisaris independen dalam perusahaan dapat mengurangi konflik perbedaan kepentingan antara pemilik perusahaan dan manajer dan menyelaraskan kepentingan pemilik perusahaan (prinsipal) dengan manajer (agen) agar memiliki tujuan yang sama. Berdasarkan hal tersebut dewan komisaris independen belum mampu menjadi faktor yang mempengaruhi besar kecilnya nilai effective tax rate.

\section{Kepemilikan manajerial berpengaruh Signifikan terhadap Effective Tax Rate (ETR)}

Hasil penelitian menunjukkan bahwa kepemilikan manajerial tidak berpengaruh signifikan terhadap Effective Tax Rate, sehingga dapat disimpulkan bahwa H4 Kepemilikan manajerial berpengaruh negatif signifikan terhadap effective tax rate (ETR) pada penelitian ini ditolak. Hasil ini sesuai dengan hasil penelitian yang dilakukan oleh Wulandari dan Dovi (2015) yang menyatakan bahwa Kepemilikan Manajerial tidak memiliki hubungan signifikan terhadap Effective Tax Rate.

Hasil ini juga sesuai dengan penelitian yang dilakukan Ayuningtyas (2018) hal ini dikarenakan persentase kepemilikan manajerial yang tergolong kecil dibandingkan investor lainnya mengakibatkan manajer tidak dapat mempengaruhi kebijakan manajemen dalam penyusunan kebijakan pengelolaan pajak efektif Hadi dan Mangoting (2014), rata-rata persentase kepemilikan saham manajerial yang relatif kecil mengindikasi bahwa perusahaan dikendalikan oleh pemegang saham lainnya. Peran manajer sekaligus sebagai pemilik tidak mampu berjalan dengan baik. Manajer belum merasa ikut memiliki perusahaan, sehingga manajer cenderung tidak memiliki motivasi untuk melakukan pengelolaan pajak yang dapat memaksimalkan pengembalian bagi para pemegang saham.

Hasil ini tidak didukung teori Atribusi dimana seorang eksekutif perusahaan yang merupakan pihak yang mempunyai wewenang untuk membuat kebijakan dan menentukan keputusan berkaitan dengan operasi bisnis perusahaan. Dimana tindakannya, eksekutif dipengaruhi faktor internal yang ada di dalam dirinya yaitu motivasi sebagai akibat dari atribut yang dimilikinya. Dengan adanya kepemilikan saham, seorang eksekutif juga menjadi bagian dari pemilik perusahaan. Sehingga, keputusan yang berkaitan dengan operasi bisnis dapat dilakukan lebih baik bila adanya kepimilikan oleh manajemen. Berdasarkan hal tersebut kepemilikan manajerial belum mampu menjadi faktor yang mempengaruhi besar kecilnya nilai effective tax rate.

\section{SIMPULAN}

Berdasarkan hasil dan pembahasan, maka hasil penelitian dapat di simpulkan sebagai berikut:

Intensitas modal tidak berpengaruh signifikan terhadap effective tax rate. Maka dari itu hipotesis pertama (H1) intensitas modal berpengaruh negatif signifikan terhadap effective tax rate (ETR) ditolak. Hal ini karena perusahaan yang sudah besar biasanya aset tetap yang digunakan sudah habis masa manfaatnya. Hal ini mengakibatkan besar kecilnya aset tetap yang dimiliki oleh perusahaan tidak berpengaruh terhadap Effective Tax Rate. Intensitas persediaan 
berpengaruh signifikan terhadap effective tax rate. Maka dari itu hipotesis kedua $\left(\mathrm{H}_{2}\right)$ Intensitas persediaan berpengaruh positif signifikan terhadap effective tax rate (ETR) diterima. Hal ini karena perusahaan lebih memilih meminimalkan ETR dengan menggunakan utang, menginvestasikan lebih besar pada aset tetap dan memiliki investasi yang rendah pada persediaan, atau kata lain perusahaan lebih memilih intensitas persediaan yang tinggi d memiliki ETR yang tinggi pula dibandingkan memuncukan biaya tambahan yang berkaitan dengan persediaan antara lain biaya penyimpanan ataupun biaya kerusakan barang.

Komisaris independen tidak berpengaruh signifikan terhadap effective tax rate. Hal ini menunjukkan bahwa keberadaan komisaris indepeden yang ada hanya sekedar memenuhi ketentuan peraturan yang ada saja dan tidak berdampak terhadap kebijakan perusahaan termasuk kebijakan perpajakan. Kebijakan perpajakan yang dilakukan manajemen tidak terawasi, sehingga kebijakan pembayaran pajak menjadi lemah. Hipotesis ketiga $\left(\mathrm{H}_{3}\right)$ yang menyatakan dewan komisaris independen berpengaruh positif signifikan terhadap effective tax rate (ETR) pada penelitian ini ditolak.

Kepemilikan manajerial tidak berpengaruh signifikan terhadap effective tax rate. Maka dari itu hipotesis keempat $\left(\mathrm{H}_{4}\right)$ yang menyatakan kepemilikan manajerial berpengaruh negatif signifikan terhadap effective tax rate (ETR) ditolak. Hal ini menunjukkan bahwa tinggi atau rendahnya kepemilikan saham oleh manajer tidak akan mempengaruhi besar atau kecilnya terhadap nilai effective tax rate.

Berdasarkan kesimpulan dari hasil penelitian, peneliti memberikan saran dalam penelitian ini, diantara yaitu:

Intensitas modal dalam penelitian ini mengunakan metode pendekatan terhadap aset tetap yang menghasilkan nilai yang rendah. Karena perusahaan yang sudah besar biasanya asset tetap yang digunakan sudah habis masa manfaatnya, sehingga besar kecilnya nilai aset tetao tidak berpengruh pada ETR. Penelitian selanjutnya untuk mengukur intensitas modal dapat menggunakan metode lainya seperti pendekatan persediaan barang, atau jika mengunakan metode pendekatan aset tetap dapat memilih perusahaan yang lebih menonjolkan aset tetap seperti perusahaan properti.

Tingkat kepemilikan manajerial di dalam perusahaan masih tergolong kecil dilihat dari tingkat persentase jumlah saham manajemen. Oleh sebab itu perusahaan dapat meningkatkan tingkat kepemilikan manajerialnya, dengan adanya kepemilikan manajerial dapat menekan masalah keagenan, dan semakin besar tingkat kepemilikan manajerial maka manajemen akan lebih giat untuk meningkatkan kinerjanya karena manajemen memiliki tanggung jawab untuk memenuhi keinginan dari pemegang saham yang tidak lain adalah dirinya sendiri dengan mengurangi resiko keuangan perusahaan melalui penurunan tingkat hutang.

\section{DAFTAR PUSTAKA}

Amelia, V. 2014. Pengaruh Ukuran Perusahaan, Leverage, Profitabilitas, Intensitas Aset Tetap, Intensitas Persediaan dan Komisaris Independen Terhadap Effective Tax Rate. 203.

Ardyansah, dan Zulaikha. 2014. Pengaruh Size, Leverage, Profitability, Capital Intensity Ratio Dan Komisaris Independen Terhadap Effective Tax Rate (ETR). Diponegoro Journal of Accounting. 3(2): 1-9.

Ayuningtyas, R. 2018. Determinat Effective Tax Rate dari Sudut Pandang Corporate Governance dan Kepemilikan Saham Publik.

Bakri, N. 2008. Analisis Hubungan dan Pengaruh Independensi dan Pengalaman Dewan Komisaris Terhadap Cost Of Deb. Thesis. Jakarta: Universitas Indonesia.

Boediono, G. 2005. Kualitas Laba: Studi Pengaruh Mekanisme Corporate Governance dan Dampak Manajemen Laba dengan Menggunakan Analisis Jalur. Prosiding. Disajikan dalam Simposium Nasional Akuntansi (SNA) VIII Solo. 
Boussaidi, A. 2015. The Impact of Goverance Mechanism on Tax Aggressiveness: Empirical Evidence From Tunissian Context. Journal of Asian Business Strategy. 5(1).

Chiao, \& Immordino-Yang. 2013. Modularity and the Cultural Mind: Contributions of Cultural Neuroscience to Cognitive Theory. Perspectives on Psychological Science. 8(1): 56-61.

Chiou, Hsieh, \& Lin. 2015. Determinants of effective tax rates for firms listed on Chinese stock market: Panel models with two-sided censors. Journal of Economic \& Financial Studies. 3(1): 306-312.

Damayanti, F. dan T. S. 2015. Pengaruh Komite Audit, Kualitas Audit, Kepemilikan Institusional, Risiko Perusahaan Dan Return On Assets Terhadap Tax Avoidance. Jurnal Bisnis Dan Manajemen. 5.

Hadi dan Yenni. M. 2014. Pengaruh Struktur Kepemilikan dan Karakteristik Dewan Terhadap Agresivitas Pajak. Tax And Accounting Review. 4: 1-10.

Hanum. 2013. Pengaruh Karakteristik Corporate Governance Terhadap Effective Tax Rate. Diponegoro Journal of Accounting. 1-54.

Ikhsan dan Ishak. 2005. Akuntansi Keprilakuan. Jakarta: Salemba Empat.

Karayan, J. E. and C. W. Swenson. 2007. Strategic Business Tax Planning (2nd editio). New Jersey: John Wiley \& Sons Inc.

Kartika Pertiwi. 2016. Pengaruh Intensitas Modal. Leverage, Intensitas Persediaan, Transaksi Perusahaam, dan transfer Pricing Terhadap Tarif Pajak Efektif. 1-15.

Liu .2007. Determinants of Corporate Effective Tax Rates. The Chinese Economy, PSAK No.14. Tentang Persediaan.

Rodriguez, dan Arias. 2013. Do Business Characteristics Determine an Effective Tax Rate? The Chinese Economy.

Sabli, Noor. 2012. Tax Planning and Coporate Governancet.

Vidiyanna dan Rizal Putri. 2018. Analisis Faktor Yang Mempengaruhi Effective Tax Rate. Jurnal Politeknik Caltex Riau. 11(1): 42-51.

Wulandari, M. dan Dovi. S. 2015. Effective Tax Rate: Efek dari Corporate Governance. Jurnal Politeknik Negeri Batam. 1-6.

Www.idx.co.id. Diakses pada 1 Maret 2019.

Yeye, S., Widyawat Ratih, \& Nuraini. 2018. Intensity Ratio dan Komisaris Independen Terhadap Effective Tax Rate. 796-804.

Zain, M. 2008. Manajemen Perpajakan. Jakarta: Salemba Empat. 